\title{
LRRTM2 wt Allele
}

National Cancer Institute

\section{Source}

National Cancer Institute. LRRTM2 wt Allele. NCI Thesaurus. Code C88989.

Human LRRT M2 wild-type allele is located in the vicinity of $5 q 31.2$ and is approximately 6 $\mathrm{kb}$ in length. This allele, which encodes leucine-rich repeat transmembrane neuronal protein 2 , may be involved in both the development and maintenance of the nervous system. 